\title{
Meat quality of white and natural colored male lambs raised in the Pampa Biome ${ }^{1}$
}

\author{
Pablo Tavares Costa*2, Jaqueline Schneider Lemes ${ }^{3}$, Gilson de Mendonça ${ }^{4}$, Michelle da Silva Gonçalves ${ }^{5}$, \\ Rômulo Tavares Costa ${ }^{6}$, Thiago Pereira Vieira ${ }^{7}$
}

$10.1590 / 0034-737 X 201764020001$

\begin{abstract}
Sheep meat quality is influenced by a number of factors either intrinsic (species, breed, sex, and age) or extrinsic (nutrition, environment, and pre- and post-slaughter handling) to the animal. However, it is not known whether wool fiber color variations within the same breed can influence the instrumental and sensory characteristics of the meat. Thus, the objective of this study was to investigate the effect of the genetic group on the instrumental and sensory characteristics of meat of white and natural colored Corriedale lambs. The 29 lambs (13 natural colored and 16 white) used in the experiments were raised on natural pasture under extensive grazing conditions in the region of the Pampa Biome, Rio Grande do Sul, Brazil. The animals were slaughtered at average age of 18 months. Meat evaluations were performed on samples from longissimus dorsi muscles. The analysis of variance was used to evaluate the effect of the genetic group and the means were compared by the $\mathrm{F}$ test. The instrumental analysis showed that meat of natural colored lambs had darker red color, higher $24 \mathrm{~h} \mathrm{pH}$, and higher scores for fat cover and texture. Sensory profiling was performed by nine trained panelists in four sessions. The sensory evaluation showed that natural colored lambs had darker red color, higher scores of fat taste and characteristic taste to the species. Despite significant differences in some sensory aspects, the samples were equally accepted by the panelists. Meat of natural colored Corriedale lambs had different instrumental and sensory profiles from that of white lambs.
\end{abstract}

Keywords: Ovis aries; sensory analysis; longissimus dorsi; Instrumental analysis.

\section{RESUMO}

\section{Qualidade da carne de cordeiros Corriedale brancos e naturalmente coloridos criados no Bioma Pampa}

Fatores intrínsecos (espécie, raça, sexo e idade) e extrínsecos ao animal (nutrição, ambiente e manejos pré e pósabate) interferem na qualidade da carne ovina. Contudo, não se sabe como variações da coloração das fibras de lã dentro de uma mesma raça podem influenciar as características instrumentais e sensoriais da carne. Assim, objetivou-se com este trabalho investigar o efeito do grupo genético dos animais sobre as características instrumentais e sensoriais da carne de cordeiros Corriedale naturalmente coloridos e brancos. Foram utilizados 29 animais ( 13 naturalmente coloridos e 16 brancos), criados na região do Bioma Pampa, no Rio Grande do Sul, em condições extensivas de pastagem natural melhorada e abatidos com idade média de 18 meses. As avaliações da carne foram realizadas no músculo longissimus

\footnotetext{
Submitted on May $24^{\text {th }}, 2015$ and accepted on November $11^{\text {th }}, 2016$.

${ }^{1}$ This work is part of the project 'Characterization of the production and commercialization of natural colored sheep raised in the Pampa Biome', financed by the National Council for Scientific and Technological Development (CNPq).

${ }_{2}^{2}$ Pinheiro Machado, Rio Grande do Sul, Brazil. pablocostta@hotmail.com.br

${ }^{3}$ Universidade Federal de Santa Maria, Departamento de Zootecnia e Ciências Biológicas, Palmeira das Missões, Rio Grande do Sul, Brazil. schneiderlemes@yahoo.com.br

${ }^{4}$ Universidade Federal de Pelotas, Departamento de Fisiologia e Farmacologia, Capão do Leão, Rio Grande do Sul, Brazil. gilsondemendonca@gmail.com

${ }^{5}$ Universidade de Caxias do Sul, Caxias do Sul, Rio Grande do Sul, Brazil. chellevetrs@yahoo.com.br

${ }^{6}$ Universidade Federal de Pelotas, Departamento de Zootecnia, Capão do Leão, Rio Grande do Sul, Brazil. romulo.tcosta@hotmail.com

${ }^{7}$ Cooperativa Central Gaúcha Ltda, Porto Alegre, Rio Grande do Sul, Brazil. thiagopereira@zootecnista.com.br

'Corresponding author: pablocostta@hotmail.com
} 
dorsi. Foi utilizada a análise de variância para avaliar o efeito do grupo genético e as médias foram comparadas pelo teste F. Na análise instrumental a carne de cordeiros naturalmente coloridos apresentou coloração mais escura e valores de $\mathrm{pH}$ 24 horas, escore de cobertura de gordura e textura mais elevados. A caracterização sensorial foi obtida em quatro sessões utilizando nove julgadores treinados. Nesta avaliação, animais naturalmente coloridos apresentaram coloração da carne mais escura, sabor à gordura e sabor característico à espécie mais elevadas. Apesar de diferenças significativas em alguns aspectos sensoriais, as amostras foram igualmente aceitas pelos julgadores. Cordeiros Corriedale naturalmente coloridos apresentam características instrumentais e sensoriais da carne distintas de cordeiros brancos.

Palavras chave: Ovis aries; análise sensorial; longissimus dorsi; análise intrumental.

\section{INTRODUCTION}

Sheep rearing is a profitable alternative for Brazilian agribusiness, capable of increasing the profitability of farms in several regions because of the increasing demand for sheep meat and the adequate conditions for the country to expand production.

In Rio Grande do Sul, natural pastures are the main forage resource for sheep farming (Sebrae/Senar/Farsul, 2005). The natural pastures of the Pampa Biome, which covers the southern half of the state, feed a large part of the cattle and sheep populations raised extensively due to the productive potential of these pastures and great floristic diversity (Boldrini, 1997).

The sheep herd of the Pampa Biome region is formed by wool and/or dual purpose breeds, among which Corriedale sheep are the most representative. Natural colored sheep, which may appear in all breeds spontaneously, are becoming an alternative of production and income for the sheep farming as it can add greater value to by-products. Thus, the natural colored sheep production has potential for expansion due to the increasing demand for natural products, enabling sustainable production with low environmental impact.

A number of studies have confirmed the potential of Corriedales to produce high quality meat in Rio Grande do Sul (Macedo et al., 2000; Azeredo et al., 2005; Osório et al., 2005; Rota et al., 2006; Jardim et al., 2007; Costa et al., 2009; Osório et al., 2013). However, there is little information on the influence of the genetic alterations that determine the appearance of dark pigmented wool fibers in Corriedales (Rota et al., 2007; Costa et al., 2009; Osório et al., 2009) on meat quality.

The last decade was characterized by important changes in the eating habits of meat consumers (Hoffman et al., 2003). According to Costa et al. (2008), the demand for healthier foods and higher quality products drove part of the market to consume meats with better nutritional and sensory quality.
Several factors interfere in sheep meat quality, and according to Osório et al. (2013), they can be classified as intrinsic (species, breed, sex and age) and extrinsic (nutrition, environment and pre- and post-slaughter handling) to the animal. These factors affect the tissue and biochemical structure of the muscle, acting on the sensory and technological attributes of the meat (Teixeira et al., 2010).

Gomes et al. (2013) identifies appearance, softness, juiciness and taste as the main factors that influence the reaction of whether or not to like a particular portion of meat; these attributes are directly influenced by the animal's age, sex, breed and feeding system. In this way, meat sensory evaluation allows us to know the consumer market's preference and, consequently, to establish the quality of the product that provides a greater degree of satisfaction.

However, few studies characterize the instrumental and sensory attributes of sheep meat in Brazil, and this lack of information is more pronounced when considering natural colored sheep. Thus, the objective of this work was to investigate the effect of the sheep genetic group on instrumental and sensory characteristics of natural colored and white Corriedale lamb meat.

\section{MATERIAL AND METHODS}

The experiment was carried out in a private farm in the municipality of Dom Pedrito, in the region of Campanha, Rio Grande do Sul, located between the coordinates $30^{\circ} 15^{\prime} 28^{\prime \prime}$ and $31^{\circ} 49^{\prime} 12^{\prime \prime}$ south latitude and $53^{\circ} 28^{\prime} 08^{\prime \prime}$ and $53^{\circ} 31^{\prime \prime 5} 8^{\prime \prime}$ west longitude, in natural pastures of the Pampa Biome. A total of 29 Corriedale lambs from two genetic groups [13 natural colored (NC) and 16 white (WH)] with average age of 18 months were used in the experiment. The lambs used in the study came from the mating of Corriedale sheep in the respective groups, that is, white lambs from the mating of white Corriedales with white Corriedales and natural colored lambs from the mating of 
natural colored Corriedales with natural colored Corriedales.

The lambs were born between August and September 2009 and raised in improved native pasture containing ryegrass (Lolium multiflorum), birdsfoot trefoil (Lotus corniculatus) and white clover (Trifolium repens).

The slaughter was carried out when the lambs reached a minimum weight of $40 \mathrm{~kg}$ and individual body condition scores between 3.0 and 3.5 in a refrigerated slaughterhouse under state inspection, according to the humane handling regulations established by CISPOA (Coordination of Industrial and Sanitary Inspection of Animal Products) of the state of Rio Grande do Sul.

The $\mathrm{pH}$ was measured immediately post-mortem in the longissimus dorsi muscle, between the 12th and 13th ribs, using a Marte MB $10 \mathrm{pH}$-meter with penetration electrode, as described by Osório \& Osório (2005). Carcasses were stored in a cold chamber at average temperature of $1{ }^{\circ} \mathrm{C}$ with forced air. After a chilling period of 18 hours, carcasses were removed from the chamber and split longitudinally, at midline.

The half-carcasses were sectioned between the 12th and 13th ribs and the subjective characteristics (texture, marbling and color) were evaluated on the surface of the longissimus dorsi muscle (Osório \& Osório, 2005).

The $\mathrm{pH}$ was measured again 24 hours post mortem in the longissimus dorsi muscle, which was excised from the carcass, packed, and frozen at $-18{ }^{\circ} \mathrm{C}$ for further sensory and instrumental analysis.

Instrumental and sensory analyzes of meat were carried out at the Carcasses and Meats Laboratory of the Department of Animal Science - FAEM - Federal University of Pelotas.

The samples of the longissimus dorsi muscle were thawed at $4{ }^{\circ} \mathrm{C}$ for $24 \mathrm{~h}$ for the instrumental analyzes (physical-chemical). Color determination was performed with a Chroma Meter CR-310 colorimeter (Minolta, Osaska, Japan), using the $\mathrm{L}^{*}, \mathrm{a}^{*}, \mathrm{~b}^{*}$ coordinates, where $\mathrm{L}^{*}$ (lightness), $\mathrm{a}^{*}$ (intensity of the red color) and $\mathrm{b}^{*}$ (intensity of the yellow color). The analysis of water holding capacity (WHC) was carried out with the pressure method (Sierra, 1973). The resulting meat sample was weighed again on a digital scale to determine the lost water. The result was expressed as the amount of water retained in relation to the initial weight of the sample.

The sensory analysis was performed in four sessions with nine trained panelists, according to Meilgaard et al. (1999), evaluating 14 replicates of each of the two treatments. The samples were thawed at $4{ }^{\circ} \mathrm{C}$ for 24 hours, wrapped in aluminum foil and placed on an preheated electric grill (Black \& Decker, GS 1600, Brazil) until reaching the internal temperature of $75{ }^{\circ} \mathrm{C}$ measured with a penetration thermometer. Then, the samples were cut parallel to the muscle fibers into $1.5 \mathrm{~cm}$ cubes, coded with three-digit numbers and served at a temperature of $60{ }^{\circ} \mathrm{C}$. The samples were analyzed in individual booths and evaluated according to the following attributes: color intensity, characteristic odor, fat odor, characteristic taste, fat taste, hardness, fibrousness, juiciness and the overall acceptance by hedonic test using a structured scale of 9 $\mathrm{cm}$, anchored to the left by the term 'weak' and to the right by the term 'strong' (Stone \& Sidel, 1998).

The experiment was arranged in a completely randomized design. The analysis of variance examined the effect of the genetic group ( $\mathrm{NC}$ or $\mathrm{WH}$ ) and the means were compared by the $\mathrm{F}$ test using the statistical program SAS (2001), with 5\% significance level. The statistical

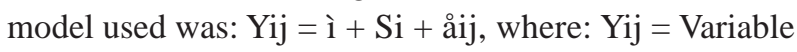
studied; ì = Mean overall; $\mathrm{Si}=$ effect of the genetic group; i (1 = NC and $2=\mathrm{WH})$; åij = Experimental error.

In the model described above, the following variables were considered as dependent variables: $0 \mathrm{~h} \mathrm{pH}$ (measured immediately post-mortem), $24 \mathrm{~h} \mathrm{pH}$ (measured 24 hours post-mortem), fat cover thickness (FCT), marbling, texture, water holding capacity (WHC), color, lightness, $a *$ red content, $b^{*}$ yellow content, characteristic odor and taste, fat odor and taste, hardness, fibrousness, juiciness and overall acceptance; and as independent variable: natural colored or white lambs.

\section{RESULTS AND DISCUSSION}

There was no significant difference for $\mathrm{Oh} \mathrm{pH}$ between the different genetic groups ( $p>0.05)$. However, higher values of $24 \mathrm{~h} \mathrm{pH}$ were found for natural colored carcasses $(\mathrm{p}<0.05)($ Table 1$)$.

However, Silva Sobrinho et al. (2005b) found no differences for $24 \mathrm{~h} \mathrm{pH}$ among the genotypes Romney, East Friesian $\mathrm{x}$ (Finn $\mathrm{x}$ Texel) and Finn $\mathrm{x}$ Poll Dorset, with mean value of 5.59 for the three genotypes evaluated.

The mean values found for $24 \mathrm{~h} \mathrm{pH}$ in NC lambs are consistent with those of Silva Sobrinho et al. (2005a) and Bonacina et al. (2011) who studied lambs Ideal x Ile de France and Texel x Corriedale, respectively. However, these values are in the lower limit of the range considered as normal for $24 \mathrm{~h} \mathrm{pH}$ in the literature, since, Young et al. (2004) argues that the final $\mathrm{pH}$ considered normal varies in the range of 5.4-5.6. According to this scale, the $24 \mathrm{~h} \mathrm{pH}$ of WH lambs can be considered low, but apparently it caused no reduction in meat quality of these animals. In addition, as noted by Sañudo (2004), there is a trend for the final $\mathrm{pH}$ to become lower with increasing age. As the lambs used in this study were on average 18 months old, it is assumed that the final $\mathrm{pH}$ was reduced due to their older age.

There were significant differences in fat cover thickness (FCT), with NC lambs having fatter carcasses $(\mathrm{p}<0.05)$. 
WH lambs had mean FCT similar to that found by Macedo et al. (2000): $1.36 \mathrm{~cm}$ for lambs of the same breed and color finished in Bermuda grass (Cynodon dactylon). NC lambs had thicker FCT, which may indicate that this genetic group has better ability for fat deposition.

There were no significant differences in the degree of meat marbling between the different groups $(\mathrm{p}>0.05)$. The mean marbling value of the carcasses was higher than that found by Rota et al. (2004), which was 1.32 for Texel $\times$ Corriedale male lambs raised in natural pasture with concentrate supplementation. This result can be considered normal, since the crossing of the breed Corriedale with a meat-type breed is expected to produce leaner carcasses.

In the texture evaluation, the objective analysis showed that NC lambs had slightly thinner fibers than WH lambs $(p<0.05)$. Texture consists of a bundle of muscle fibers grouped in fascicles enveloped by a layer of connective tissue (perimysium) and evaluated subjectively by the granulation of the muscle surface when being cut (Restle et al., 2002). A thin texture, which indicates a smaller diameter of the muscular fibers, gives a better appearance and indicates that the meat comes from a young animal and is therefore softer (Osório \& Osório, 2005). However, in sheep, this trend is not always confirmed. Rota et al. (2006) evaluated subjectively the meat texture in lambs of 4, 7 and 12 months of age and found no differences among them. But Gularte et al. (2000) studied 7-, 8- and 9-monthold Corriedale lambs and found higher scores for meat texture of 7-month-old sheep. Because the lambs used in the present study had similar ages at slaughter, the differences observed in meat texture could be attributed to a greater accumulation of connective tissue in WH lambs.

No significant differences were observed between the genotypes $(p>0.05)$ for water holding capacity (WHC). However, the values of WHC found in this study were lower than those reported by other published studies (Rota et al., 2004; Bonacina et al., 2011), which may be related to the $\mathrm{pH}$ found, since the variations in water holding capacity are related to the rate of $\mathrm{pH}$ reduction during rigor mortis and its final value; the greater the $\mathrm{pH}$, the greater the capacity to retain water (Lawrie, 2005).

Color plays an important role on meat sensory quality and stands out as the main factor of appreciation at the time of purchase (Costa et al., 2008). Meat from natural colored animals was classified as darker $(\mathrm{p}<0.05)$ by both the colorimeter and the panel analysis (Table 2).

According to Silva Sobrinho et al. (2005b), muscle color is determined by the amount of myoglobin and the relative proportions of this pigment. Osório et al. (2009) discuss that $\mathrm{pH}$ influences the stability of sheep meat color, and one should consider the final $\mathrm{pH}$ at rigor mortis and its drop during pre-rigor, since meats with high $\mathrm{pHs}$ have darker color due to greater light absorption. Dhanda et al. (2003) argue that the genetic factor can influence meat color by the deposition of pigments in muscle or adipose tissue. It seems possible that the darker color in the meat of natural colored lambs is due to higher values of $24 \mathrm{~h} \mathrm{pH}$ and genetic factors.

Although there were no significant differences between the groups for the variables $\mathrm{L}^{*}, \mathrm{a}^{*}$, and $\mathrm{b}^{*}$, the meat of NC and WH Corriedale lambs was redder than that of Santa Inês sheep (Madruga et al., 2005), whose mean values were $L^{*}$ (39.76 to 42.96$)$, $a^{*}$ (12.81 to 14.22$)$ and $b^{*}$ (9.04 to 10.16).

No significant differences ( $p>0.05$ ) were found for the parameters characteristic odor and fat odor, although NC animals had slightly higher values of these attributes.

The panelists identified that meat from NC lambs had a more pronounced characteristic taste and fat taste $(\mathrm{p}<$ 0.05 ) than meat from WH lambs, which was already expected because NC lambs showed higher values of FCT ( $p>0.05)$ and because the characteristic taste of sheep meat is

Table 1: Means and standard errors for the physical-chemical characteristics of meat of natural colored (NC) and white (WH) lambs

\begin{tabular}{lccl}
\hline Parameter $^{(1)}$ & \multicolumn{2}{c}{ Genetic Group } & F Test \\
\cline { 2 - 3 } & NC & WH & $0.2739 \mathrm{~ns}$ \\
Oh pH & $6.37 \pm 0.1$ & $6.19 \pm 0.1$ & $0.0192 *$ \\
24h pH & $5.43 \pm 0.1$ & $5.09 \pm 0.1$ & $0.0092 * *$ \\
FCT & $2.07 \pm 0.3$ & $1.31 \pm 0.1$ & $0.0371 *$ \\
Texture & $2.73 \pm 0.2$ & $2.25 \pm 0.1$ & $0.0009 * *$ \\
Color & $3.11 \pm 0.1$ & $2.34 \pm 0.1$ & $0.0980 \mathrm{~ns}$ \\
Marbling & $1.53 \pm 0.2$ & $2.06 \pm 0.2$ & $0.3096 \mathrm{~ns}$ \\
L & $41.27 \pm 0.8$ & $42.44 \pm 0.8$ & $0.0567 \mathrm{~ns}$ \\
a* & $15.84 \pm 0.5$ & $14.4 \pm 0.5$ & $0.2690 \mathrm{~ns}$ \\
$\mathrm{~b}^{*}$ & $10.39 \pm 0.7$ & $9.34 \pm 0.6$ & $0.6989 \mathrm{~ns}$ \\
WHC & $3.88 \pm 0.1$ & $3.90 \pm 0.1$ & \\
\hline
\end{tabular}

${ }_{\mathrm{ns}}$ Non-significant. $* *$ Significant at $1 \%$ probability. * Significant at $5 \%$ probability.

(1) FCT, fat cover thickness; L, brightness; a, red content; b, yellow content; WHC, water holding capacity. 
directly related to the fat content in the muscle (Osório et al., 2009). Madruga et al. (2005) studied the meat quality of Santa Inês lambs finished with different diets and also found that the meat with greater fat content had more intense characteristic taste of sheep meat.

No significant difference was detected for the attributes hardness, juiciness and fibrousness $(\mathrm{p}>0.05)$. The mean values for hardness were similar to those found by Bonacina et al. (2011), mean of 3.75 for Texel x Corriedale lambs finished in pasture.

Although some sensory characteristics showed significant differences between the groups, no differences
( $p>0.05)$ were observed for the overall acceptance of the samples, confirming that the genetic group has no effect on the preference of trained panelists.

The overall acceptance values are considered low (Table 2), probably because some of the panelists do not consume sheep meat frequently, thus being unfamiliar with the product. This result agrees the finding of Font I Furnols et al. (2006), who studied the acceptance of lamb meat by consumers in different European countries and concluded that one of the factors influencing meat acceptance is the eating habit.

Table 2: Means and standard errors of the sensory analysis of meat of natural colored (NC) and white (WH) lambs

\begin{tabular}{lccc}
\hline \multirow{2}{*}{ Parameter $^{(\mathbf{1})}$} & \multicolumn{2}{c}{ Genetic Group } & F Test \\
\cline { 2 - 3 } & NC & WH & $0.0001 * *$ \\
Color & $4.78 \pm 0.1$ & $3.92 \pm 0.1$ & $0.2901 \mathrm{~ns}$ \\
Characteristic odor & $4.60 \pm 0.1$ & $4.40 \pm 0.1$ & $0.1201 \mathrm{~ns}$ \\
Fat odor & $3.78 \pm 0.2$ & $3.46 \pm 0.1$ & $0.0302 *$ \\
Characteristic taste & $4.96 \pm 0.1$ & $4.51 \pm 0.1$ & $0.0137 *$ \\
Fat taste & $3.67 \pm 0.1$ & $3.17 \pm 0.1$ & $0.1926 \mathrm{~ns}$ \\
Hardness & $3.91 \pm 0.1$ & $3.7 \pm 0.1$ & $0.3908 \mathrm{~ns}$ \\
Juiciness & $3.33 \pm 0.1$ & $3.16 \pm 0.1$ & $0.0621 \mathrm{~ns}$ \\
Fibrousness & $3.52 \pm 0.1$ & $3.91 \pm 0.1$ & $0.0901 \mathrm{~ns}$ \\
Overall acceptance & $4.09 \pm 0.1$ & $3.74 \pm 0.1$ & \\
\hline
\end{tabular}

${ }^{\mathrm{ns}}$ Non-significant. ${ }^{* *}$ Significant at $1 \%$ probability. $*$ Significant at $5 \%$ probability.

\section{CONCLUSIONS}

Natural colored Corriedale lambs have darker meat with higher texture values, $\mathrm{pH}$ measured 24 hours post mortem, fat cover score and more intense fat taste and characteristic taste of sheep. The genetic group has no effect on the acceptance of the Corriedale lamb meat by the panelists.

\section{ACKNOWLEDGEMENTS}

The authors thank the National Council for Scientific and Technological Development (CNPq) for the financial support to the project; the Foundation for Research Support of the State of Rio Grande do Sul (FAPERGS) for granting of a scholarship; and PAP São Pedro, for the facilities and technical support.

\section{REFERENCES}

Azeredo DM, Osório MTM, Osório JCS, Mendonça G, Barbosa J \& Esteves RM (2005) Crescimento e desenvolvimento de ovinos Corriedale não castrados, castrados e criptorquidas abatidos com diferentes pesos. Revista Brasileira Agrociência, 11:339345

Bonacina MS, Osório MTM, Osório JCS, Corrêa GF \& Hashimoto JH (2011) Influência do sexo e do sistema de terminação de cordeiros Texel x Corriedale na qualidade da carcaça e da carne. Revista Brasileira de Zootecnia, 40:1242-1249.
Boldrini II (1997) Campos do Rio Grande do Sul: Caracterização fisionômica e problemática ocupacional. Porto Alegre, UFRGS. 39p. (Boletim do Instituto de Biociências, 56).

Costa JCC, Osório JCS, Osório MTM, Faria HV, Mendonça G \& Esteves RM (2009) Produção de carne de ovinos Corriedale terminados em três sistemas de alimentação. Revista Brasileira de Agrociência, 15:83-87.

Costa RG, Cartaxo FQ, Santos NM \& Queiroga RCRE (2008) Carne caprina e ovina: composição lipídica e características sensoriais. Revista Brasileira de Saúde e Produção Animal, 9:497-506.

Dhanda JS, Taylor DG \& Murray PJ (2003) Growth, carcass and meat quality parameters of male goats: effects of genotype and live weight at slaughter. Small Ruminant Research, 50:57-66.

Font I Furnols MF, Julián RS, Guerrero L, Sañudo C, Campo MM, Olleta JL, Oliver MA, Cañeque V, Alvarez I, Díaz MT, Branscheid W, Wicke M, Nute GR \& Montosse F (2006) Acceptability of lamb meat from different producing systems and ageing time to German, Spanish and British consumers. Meat Science, 72:545554.

Gomes C, Karam LB \& Macedo REF (2013) Atributos de qualidade da carne de paca (Agouti paca): perfil sensorial e força de cisalhamento. Arquivo Brasileiro de Medicina Veterinária e Zootecnia, 65:559-565.

Gularte MA, Treptow RO, Pouey LF \& Osório JC (2000) Idade e sexo na maciez da carne de ovinos da raça Corriedale. Ciência Rural, 30:485-488.

Hoffman LC, Muller M, Cloete SW \& Schmidt D (2003) Comparison of six crossbred lamb types: sensory, physical and nutritional meat quality characteristics. Meat Science, 65:1265-1274. 
Jardim RD, Osório JCS, Osório MTM, Mendonça G, Esteves R \& Gonçalves M (2007) Efeito da idade de abate e castração sobre a composição tecidual e química da paleta e da perna de ovinos Corriedale. Revista Brasileira de Agrociência, 13:237-242.

Lawrie RA (2005) Ciência da Carne. 6 ${ }^{\mathrm{a}}$ ed. Porto Alegre, Artmed. $384 \mathrm{p}$.

Macedo FAF, Siqueira ER, Martins EM \& Macedo RMG (2000) Qualidade de carcaças de cordeiros Corriedale, Bergamácia $\mathrm{x}$ Corriedale e Hampshire Down x Corriedale, terminados em pastagem e confinamento. Revista Brasileira de Zootecnia, 29:1520-1527.

Madruga MS, Souza WHS, Rosales MD, Cunha MGG \& Ramos JLF (2005) Qualidade da carne de cordeiros Santa Inês terminados com diferentes dietas. Revista Brasileira de Zootecnia, 34:309315 .

Meilgaard M, Civille GV \& Carr BT (1999) Sensory Evaluation Techniques. $3^{\mathrm{a}}$ ed. Florida, CRC Press. 387p.

Osório JCS, Osório MTM, Mendonça G, Pereira PH, Faria HV \& Oliveira NM (2005) Morfologia e características produtivas e comerciais em cordeiros Corriedale castrados e não castrados. Revista Brasileira de Agrociência, 11:211-214.

Osório JCS, Osório MTM \& Sañudo C (2009) Características sensoriais da carne ovina. Revista Brasileira de Zootecnia (Suplemento Especial), 38:292-300.

Osório JCS \& Osório MTM (2005) Produção de carne ovina: Técnicas de avaliação "in vivo" e na carcaça. $2^{\mathrm{a}}$ ed. Pelotas, Universidade Federal de Pelotas. 82p.

Osório MTM, Bonacina MS, Osório JCS, Rota EL, Ferreira OGLF, Treptow RO, Gonçalves MS \& Oliveira MM (2013) Características sensoriais da carne de ovinos Corriedale em função da idade de abate e da castração. Revista Agrarian, 6:60-66.

Restle J, Faturi C, Bernardes RAC, Filho DCA, Menezes LFG, Souza ANM \& Carrilho CO (2002) Efeito do grupo genético e da heterose na composição física e nas características qualitativas da carcaça e da carne de vacas de descarte terminadas em confinamento. Revista Brasileira de Zootecnia, 31:1378-1387.

Rota EL, Osório MTM, Osório JCS, Barbosa NM \& Kasinger S (2004) Efeitos do cruzamento de carneiros da raça texel com ovelhas corriedale e ideal sobre a qualidade da carne. Revista Brasileira Agrociência, 10:487-491.
Rota EL, Osório MTM, Osório JCS, Oliveira MM, Wiegand MM, Mendonça G, Esteves RM \& Gonçalves M (2006) Influência da castração e da idade de abate sobre as características subjetivas e instrumentais da carne de cordeiros Corriedale. Revista Brasileira de Zootecnia, 35:2397-2405.

Sañudo C (2004) Análisis Sensorial - Calidad organoléptica de la carne. In: Curso Internacional de analise sensorial de carne e produtos cárneos, Pelotas. Anais, Universidade Federal de Pelotas. p.45-68.

SAS Institute Inc. (2002) Statistical Analysis System user's guide. Version 9.0. Cary, Statistical Analysis System Institute. 513p.

SEBRAE / SENAR / FARSUL (2005) Diagnóstico de sistemas de produção da bovinocultura de corte do Estado do Rio Grande do Sul (Relatório de Pesquisa). Porto Alegre, UFRGS / IEPE. 265p.

Sierra IA (1973) Produccion de cordero joven y pesado en la raza rasa argonesa. Instituto de Economia y Producciones Ganaderas del Ebro/Universidad de Zaragoza. 23p. (Boletín técnico, 18).

Silva Sobrinho AG, Purcha RW, Kadim IT \& Yamamoto SM (2005b) Características de qualidade da carne de ovinos de diferentes genótipos e idades ao abate. Revista Brasileira de Zootecnia, 34:1070-1078.

Silva Sobrinho AG, Silva AMA, Gonzaga Neto S, Zeola NMBL, Marques CAT \& Miyagi ES (2005a) Parâmetros qualitativos da carcaça e da carne de cordeiros submetidos a dois sistemas de formulação de ração. Agropecuária Científica no Semi-Árido, $1: 31-38$.

Stone H \& Sidel JL (1998) Quantitative descriptive Analysis: developments, applications and the future. Food technology, 52:48-52.

Teixeira PPM, Da Silva ASL \& Vicente WRR (2010) Castração na produção de ovinos e caprinos. Revista Científica Eletrônica de Medicina Veterinária, 8:1-15.

Young OA, Wetb J, Hartc AL \& Otterdijk FFV (2004) A method for early determination of meat ultimate $\mathrm{pH}$. Meat Science, 66:493-498. 